Archived version from NCDOCKS Institutional Repository http://libres.uncg.edu/ir/asu/

\title{
Appalachľan
}

$\bar{B}$ O O N E, N O R T H A R O L N A

\section{Technology Clusters Versus Industry Clusters: Resources, Networks, And Regional Advantages}

\author{
By: Caron H. St. John and Richard W. Pouder
}

\begin{abstract}
The tendency of firms to cluster within a region has been observed for quite some time. However, it is only over the past two decades that business researchers have focused much attention on clusters, particularly in terms of their entrepreneurial and innovative characteristics and potential. At the same time, regional developers around the world have put much effort in promoting the formation of clusters. A gap in such efforts is an understanding of the differences among types of clusters. This article draws a distinction between two generic types of clusters: technology-based and industry-focused. Using the resource-based view as the organizing framework, we argue that the two generic cluster types create very different regional resource profiles over time, accumulating resources in a different manner, cultivating different capabilities, and deriving different sources of regional advantage. As concluded in the study, these differences are likely to have implications for firms located in the regions as well as for economic developers and public policy officials charged with developing cluster strategies.
\end{abstract}

JOHN, C. H. and POUDER, R. W. (2006), Technology Clusters versus Industry Clusters: Resources, Networks, and Regional Advantages. Growth and Change, 37: 141-171. doi:10.1111/j.1468-2257.2006.00313.x. Publisher version of record available at: https://onlinelibrary.wiley.com/doi/10.1111/j.1468-2257.2006.00313.x 


\title{
Technology Clusters versus Industry Clusters: Resources, Networks, and Regional Advantages
}

\author{
CARON H. ST. JOHN AND RICHARD W. POUDER
}

\begin{abstract}
The tendency of firms to cluster within a region has been observed for quite some time. However, it is only over the past two decades that business researchers have focused much attention on clusters, particularly in terms of their entrepreneurial and innovative characteristics and potential. At the same time, regional developers around the world have put much effort in promoting the formation of clusters. A gap in such efforts is an understanding of the differences among types of clusters. This article draws a distinction between two generic types of clusters: technology-based and industry-focused. Using the resource-based view as the organizing framework, we argue that the two generic cluster types create very different regional resource profiles over time, accumulating resources in a different manner, cultivating different capabilities, and deriving different sources of regional advantage. As concluded in the study, these differences are likely to have implications for firms located in the regions as well as for economic developers and public policy officials charged with developing cluster strategies.
\end{abstract}

\section{Introduction}

D uring the last ten years, there has been increased interest in the role of regional clusters, or hot spots, in the creation of economic growth and wealth (Bresnahan, Gambardella, and Saxenian 2001; Porter 1998; Porter and van Opstal 2000; Saxenian 1994). Although economic geographers and regional scientists have observed the tendency of firms to cluster for generations (Krugman 1995; Marshall 1920; Scott 1989; Storper 1993), the new venture successes in Silicon Valley, Route 128 in Boston, and Austin, Texas, among others (Saxenian 1994), have stimulated interest in the innovation and entrepreneurial potential of clustered industries. This increased interest paralleled the explosion of new ventures in the United States in the 1990s, but has persisted through the ups and downs in the economy.

Caron St. John is a professor in the Department of Management at Clemson University in Clemson, South Carolina. She is also the director of the Spiro Center for Entrepreneurial Leadership. Her e-mail address is scaron@clemson.edu. Richard Pouder is an associate professor in the Department of Management at Appalachian State University in Boone, North Carolina. His e-mail addressispouderrw@appstate.edu. 
These interests are worldwide in scope, with regional developers and academic researchers throughout the world focusing on the lessons that can be learned from high-growth regions.

The business press has fueled the interest in cultivating regional hot spots, noting the new wave of cities and regions that have been successful in creating new jobs and new business ventures from technological discovery and invention (see The Economist 2002; Ferguson 1999; Gold 2001). The value of these regions in producing new jobs and businesses and in stimulating innovation is recognized as an important keystone in a nation's innovation infrastructure. Indeed, it has been argued that in order for regional development initiatives to stimulate new clusters, it should be an essential national priority, a key element in the nation's quest to maintain its national innovation infrastructure (Council on Competitiveness 2001). Now, virtually every state in the U.S. has a cluster development strategy as part of its economic development plan. For example, in a Brookings Institute report issued in 2002, forty-one communities were pursuing a bio-technology cluster strategy even though 75 percent of the nation's largest bio-technology firms are concentrated in just nine regions (Cortright and Mayer 2002).

As cities and regions work to cultivate the resources needed to initiate and grow a cluster, they are often advised to look for existing clusters in their region that have passed a market test and to build entrepreneurial networks needed to grow them (Rosenfeld 1997). In the rush to develop cluster-based economic development strategies, there is often a lack of clarity about what a cluster is and what efforts are required to grow one. As described by Rosenfeld (1997: 6), "for the cluster to become a legitimate and useful subject of analysis and policy, it must be defined more clearly than it has been." Furthermore, most discussions of clusters do not address subtleties in how different types of clusters are structured, the types of economic activity they perform (Feldman and Audretsch 1999), or the factors that would influence survivability over time - all of which have bearing on the long-range effectiveness of cluster development strategies.

After a review of the key underlying cluster concepts, two generic cluster types that capture key differences in the forms of economic activity undertaken in most clusters are proposed. Using the resource-based view as the organizing framework, two generic cluster types that create very different regional resource profiles over time, accumulating resources in a different manner, cultivating different capabilities, and deriving different sources of regional advantage are described. As concluded in this study, these differences are likely to have implications for firms located in the regions as well as for economic developers and public policy officials charged with developing cluster strategies.

\section{Foundation Concepts}

In setting the stage for this discussion of clusters, resources, and regional advantages, the article will first briefly highlight key foundation concepts: (1) cluster definitions and structural dimensions, with an objective of proposing two generic cluster types that are useful in explaining regional resource profiles and sources of regional advantages, and (2) the underlying dynamics of industry and technology evolution, both of which influence the relative role of innovation-seeking and efficiency-seeking in the evolution and sustainability of clusters over time. 
Cluster definition and structure. Much of the growing interest in clusters draws from the work of Alfred Marshall (1920) who developed the notion of "industrial districts" as agglomerations of firms operating in one industry sector in a well-defined and relatively small geographic area. Further conceptual development of the Marshallian industrial district incorporates the idea that such agglomerations are comprised of specialized labor, subcontractors, and a common knowledge base supported by formal and informal sociocultural interaction. In other regional innovative models, such innovative milieu and technology districts have been offered as frameworks for discussing the pattern of industry agglomeration that occurs across the world (Table 1). What distinguishes clusters from these other models has not been clearly defined and continues as a source of confusion among scholars and practitioners (Bergman and Feser 1999). Indeed, these concepts - clusters, industrial districts, innovative milieu, and technology districts - are often used almost interchangeably despite having origins in different conceptual contexts (Newlands 2003). Like clusters, other "territorial innovation models" are regional agglomerations of firms that provide a localized institutional dynamics that enhances innovation and growth in the region (Moulaert and Sekia 2003). Because there is a lack of conceptual clarity as to what constitutes a cluster, these other theories, which are antecedent to clustering models per se, are valuable contributions to the conceptual underpinnings of clustering models.

Enright (1996) defined a cluster as a group of business enterprises and nonbusiness organizations whose membership within the group is an important element of each member firm's individual competitiveness. Binding the cluster together are "buyer-supplier relationships, or common technologies, common buyers or distribution channels, or common labor pools" (Enright 1996: 191). Porter (1998: 15) defined a cluster as "an array of linked industries and other entities important to competition." Porter's main point on what differentiates clusters from historical intellectual antecedents and more recent theories of agglomeration is that clusters comprise a multiorganizational form that play a key role in competition and have a strong influence on market economies. As Porter notes,

Earlier studies have, nonetheless, contributed to our understanding of the influence of clusters on competition. The literature on agglomeration economies stresses input cost minimization, input specialization made possible because of the extent of the local market, and the advantages of locating near markets. The economic development literature focuses on induced demand and supply, certainly an element of cluster formation. The normative implication of the concept of backward and forward linkages, however, emphasizes the need to build industries with linkages to many others. Cluster theory, in contrast, advocates building on emerging concentrations of companies and encouraging the development of those fields with strongest linkages to or spillovers within each cluster. [emphasis added] (207)

The preceding definitions of clusters are general, with several types of potential relationships among firms (e.g., buyer-supplier, direct competitor, indirect competitor, and affiliated firms), all of which contribute to some of the conceptual confusion with the cluster construct. In an attempt to clarify the concept, some researchers have distinguished what appear to be structural dimensions of agglomerated firms or clusters. Maskell (2001) 
TABle 1. TerRitorial InNOVAtion Models.

\begin{tabular}{|c|c|}
\hline Concepts & Description \\
\hline $\begin{array}{l}\text { Industrial } \\
\text { districts }\end{array}$ & $\begin{array}{l}\text { On a timeline, territorial agglomeration models have a common } \\
\text { ancestry in Alfred Marshall's (1920) notion of industrial districts } \\
\text { as agglomerations of firms operating in one industry sector in a } \\
\text { well-defined and relatively small geographic area. The } \\
\text { Marshallian industrial district incorporates the idea that such } \\
\text { agglomerations are comprised of small, locally owned firms, } \\
\text { specialized labor, supporting industries that provide specialized } \\
\text { inputs and services, common knowledge base supported by } \\
\text { formal and informal sociocultural interaction, and strong } \\
\text { cooperative bonds between competitors. Proximity promotes } \\
\text { spatial externalities such as high degree of diffusion of } \\
\text { knowledge within the industrial district. Such external } \\
\text { economies are largely attributable to the social embedment of } \\
\text { industrial districts (Harrison 1992). }\end{array}$ \\
\hline $\begin{array}{c}\text { Innovative } \\
\text { milieu }\end{array}$ & $\begin{array}{l}\text { Drawing from work on industrial districts, scholars developed the } \\
\text { theory of the innovative milieu (Camagni 1991; Maillat 1991), } \\
\text { which similarly captures the importance of close spatial } \\
\text { proximity to innovation. This model views the "milieu" (i.e., } \\
\text { collective context of competing firms and supporting } \\
\text { organizations) as the source of innovation. The work on } \\
\text { innovative milieu stresses the importance of cooperative } \\
\text { inter-firm learning as a dynamic process that promotes product } \\
\text { and process innovations rather than acknowledging the efforts } \\
\text { of distinct innovative agents as posited by theorists of industrial } \\
\text { districts (Keeble and Wilkinson 1999). In sum, rather than } \\
\text { through diversified economic structures, the milieu stimulates } \\
\text { cooperation and innovation through a regional culture and } \\
\text { identity. }\end{array}$ \\
\hline $\begin{array}{l}\text { Technology } \\
\text { districts }\end{array}$ & $\begin{array}{l}\text { Like industrial milieu, technology districts draw from ideas } \\
\text { advanced in Marshallian industrial districts. As advanced by } \\
\text { Storper (1992), technology districts focus on production-based } \\
\text { technological learning that occurs among firms in technologically } \\
\text { dynamic industries situated in highly concentrated subnational } \\
\text { regions. Because vertical integration may inhibit the need to } \\
\text { respond to technological change, firms in technology districts } \\
\text { tend to organize in flexible networks. Networks are organized, } \\
\text { and thus learning takes place along the lines of conventional } \\
\text { territorial rules, based on established social, rather than } \\
\text { economic, conventions. Such networks build a foundation for } \\
\text { qualitative external economies. Later interpretations incorporate } \\
\text { the idea that technology districts are focused on a single product } \\
\text { and that firms in the district face an ongoing need to be } \\
\text { innovative and achieve economies of variety. }\end{array}$ \\
\hline
\end{tabular}


described the distinction between a cluster that is predominantly vertical, representing stages along a supply chain, and one that is predominantly horizontal, consisting primarily of rivals and competitors. Jacobs and de Man (1996), noting the broad general treatment of the concept of a cluster, reviewed the research literature and distilled six dimensions that underlie the structure and activity of geographic clusters of firms.

1. Horizontal - several direct competitors in the same or closely related industries

2. Vertical-firms in adjacent phases of the supply chain

3. Lateral-firms in different industries that share or draw from common capabilities or resources

4. Technological - firms in a collection of industries that share a basic technology

5. Focal - firms are drawn to a central entity such as a dominant firm, research center, or educational institution

6. Network quality - degree and processes of inter-firm cooperation.

Using the dimensions proposed by Jacobs and de Man (1996), a cluster may be characterized by large numbers of direct competitors, by adjacent stages in the supply chain, or by related industries that draw from a common resource or technology base, and, furthermore, may or may not be influenced by the presence of one focal organization. The dimensions do not represent "types," but rather underlying dimensions that can be used to identify cluster types, which would be a first step in improving the conceptual clarity of the cluster construct. The following section uses the terminology of Jacobs and de Man (1996) in describing cluster origination, structure, focus, and use of networks.

Cluster formation and evolution. There is generally an element of chance in the origin of a particular geographical cluster of firms (Rauch 1993). Clusters may originate from one successful start-up, giving rise to a pattern of spin-offs (Maarten de Vet and Scott 1992), or as suppliers to a successful dominant firm, or in response to other opportunities or initiatives. Although the incidence of cluster origination is inherently difficult to predict (Scott 1992), once a cluster forms, it is possible to reconstruct the evolutionary path.

In some cases, the clustering of firms in a particular location is a function of proximity to an original large customer or large market, a focal entity (Jacobs and de Man 1996), such as the tourist or entertainment cluster that has developed to serve Disney World patrons near Orlando, Florida (Archer 1997), and financial services near the stock exchanges in New York City (Porter 1998). In these examples, the clusters formed initially to exploit a vertical (buyer-supplier) relationship (Jacobs and de Man 1996) with a customer or market. Over time, as additional suppliers to the market formed or relocated to the cluster, the clusters began to take on a horizontal structure (Jacobs and de Man 1996), with companies in key supplying industries competing directly to serve the needs of the customer or market. In some cases, the growth of the horizontal cluster of suppliers may be constrained by the size of the local market opportunity. In other cases, this type of cluster may evolve an even more pronounced vertical logic over time with tiers of suppliers serving the final market, as when groups of tier 1, tier 2, and tier 3 automotive suppliers of materials, parts, and services cluster around a large automobile manufactur- 
ing facility. (See Example 1 with shading that illustrates direct industry competitors in Figure 1).

In other cases, clusters form because of (1) a tie to a physical resource found in a particular region, such as coal fields and steel mills in Pennsylvania; (2) labor with a unique

Example 1

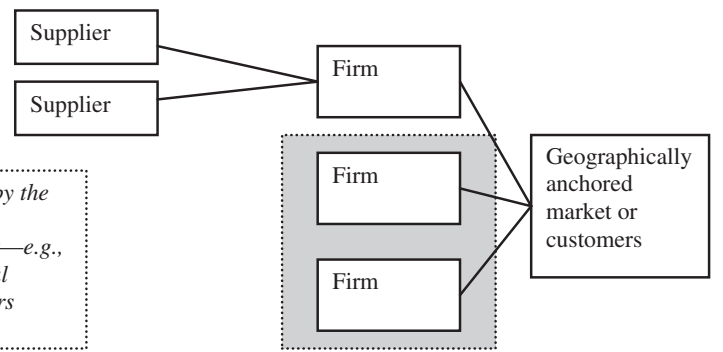

"Industry" identity defined by the cluster of direct competitors serving the anchored market-e.g., tourism, Wall Street financial services, automotive suppliers around an automotive plant.

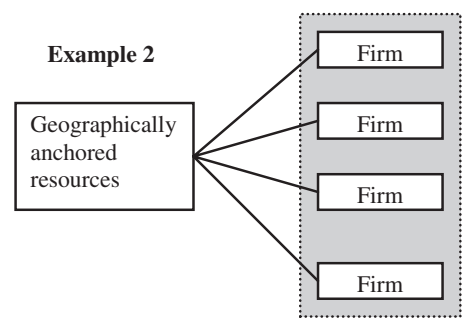

$$
\begin{aligned}
& \text { "Industry" identity } \\
& \text { defined by the } \\
& \text { groupings of } \\
& \text { competitors accessing } \\
& \text { the resource-e.g., } \\
& \text { steel, wine, furniture, } \\
& \text { shipping. }
\end{aligned}
$$

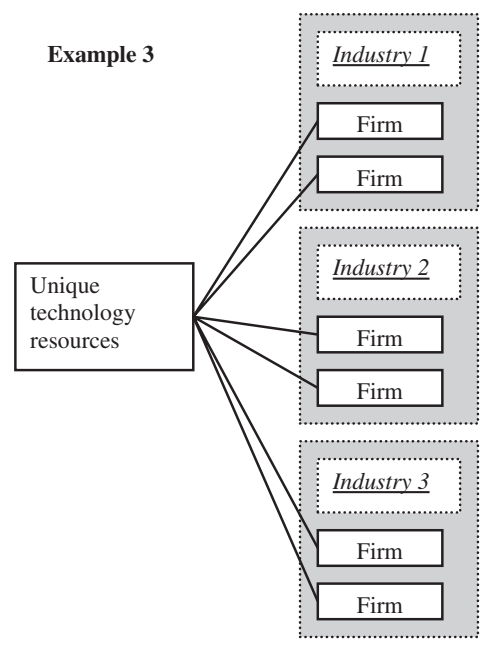

"Technology" identity, with likelihood of more than one "industry" in the cluster.

Potential for groupings of direct competitors, but dominated by diversified applications of the technology to different markets or industries. 
skill or experience set, as in the historical clustering of immigrant furniture craftsmen in Grand Rapids, Michigan (Carron 1998); (3) abundant, low-cost labor and lumber resources for furniture manufacturing in western North Carolina (Rosenfeld 1997); (4) favorable climatic and soil conditions for grape growing in the Napa Valley region of California (Porter 1998); (5) telemarketing firms' exploitation of preexisting fiber-optic telecommunications cables used to support the Strategic Air Command in Omaha, Nebraska (Porter 1998); and, (6) coastal Connecticut's cluster of maritime firms in proximity to three deepwater ports (Connecticut Maritime Coalition 2000). Clusters that form around a key geographically restricted resource often result in several like-competitors grouping in the same region to access the resource. As with the clusters that originate with a key customer or market, these clusters exhibit a vertical logic initially because of the tie to the resource, but over time they may exhibit a more horizontal structure represented by a concentration of direct competitors. In these situations, cluster growth may be constrained by the capacity or availability of the key resource. (See Example 2 with shading that illustrates direct industry competitors in Figure 1).

In all of the aforementioned examples, the cluster logic is vertical initially as geographical proximity is used to reduce the friction of transacting buyer-supplier arrangements. Over time, however, the cluster may evolve horizontally, characterized by new formations, spin-offs, or relocations leading to more firms seeking access to the market or resources. The resulting concentration of direct competitors may give the cluster an industry identity, as observed in the tourism, financial services, steel, wine, furniture, carpet, and shipping clusters, among others.

In contrast, the clusters that are used as the most common examples for economic development initiatives have evolved a technology identity rather than an industry identity, such as the original "Silicon Valley," the clustering of photonics firms in Tucson, Ottawa, and Tampa-Orlando, and the clustering of bio-technology firms in proximity to Boston, San Diego, and Seattle. In these clusters, new technologies, often developed with the participation of university researchers, provide radical new innovations that are often competencedestroying, giving rise to whole new industries and allowing entry of new firms (Darby and Zucker 2003). The products are varied and their market applications can range from consumer to industrial, military to medical. In their initial formation, these technology clusters appear as a special case of a resource-based cluster, in that knowledge and research from universities and national laboratories are often essential resources that serve as the attractors to and anchors in the region. Although some vertical supply relationships may form (particularly in the form of service and laboratory support), the discoveries often provide opportunities that exploit similarities in core technology, but differences in application and target market. For example, bio-technology clusters have exploited new combinations of knowledge resources, creating a host of related technologies that have different applications such as cell culture, genetic engineering, immunology systems, and protein engineering. Bio-technology is not an industry, but rather an overarching technology that influences several industries, including pharmaceuticals, analytical instrumentation, and agriculture, just to name a few. Similarly, electronics technology (e.g., vacuum tubes, transistors, semi- 
conductors) writ large in its various applications (communications, consumer electronics, computers) is at the core of Silicon Valley growth and identity. As noted by Zhang (2003), the strength of Silicon Valley lies in its ability to reinvent itself, as new technologies give rise to completely new industries.

Over time, the growth in these technology clusters seems far less industry-focused with a more diversified pool of firms pursuing early-stage opportunities across a variety of related industry sectors. As Patrucco (2003) points out, the horizontal indivisibility of technical knowledge often complements and builds upon advances made in seemingly unrelated areas of inquiry. "In such a context, innovation results as the output of a diffused and collective process where different knowledge bases are absorbed, recombined and shared through diverse communication channels" (162). As noted by Antonelli (2000: 541), "Proximity and co-localization within a local system favor both the intrasectoral and intersectoral dissemination of technological knowledge both vertically and horizontally.... New technological knowledge generated in one industry however often has considerable potential for direct applications in other industries." Using the cluster dimensions described by Jacobs and de Man (1996), these clusters capture a lateral dimension. Over time, it is likely that the cluster will exhibit a lateral structure, analogous to a horizontally integrated or related diversified portfolio of businesses rather than the single-industry focus described earlier. (See Example 3 in Figure 1).

The originating events and significant growth phases in the evolution of two clusters that embody the differences noted in the discussion above - the technology cluster in what is now known as Silicon Valley in California, and the carpet industry cluster in Dalton, Georgia - are profiled in Table 2. The tufted carpet industry was founded in Dalton in the early 1900s. Today, over 80 percent of all tufted carpet is produced in the same geographical area.

Industry and technology effects. A cluster has both industrial and geographical dimensions to it, therefore some of the localized economic effects are the result of industry growth and profit characteristics, which tend to track an industry life cycle (Sternberg 1996). As industries evolve from early-growth phases to maturity, innovative activity tends to shift from product innovations that fuel growth to process innovations that improve efficiencies (Abernathy and Utterback 1978). The types of innovative activities that lead to new firms and large numbers of new jobs tend to occur primarily during the early and growth phases of the industry life cycle, ultimately dissipating during the maturity phase (Audretsch and Feldman 1996). Consequently, by extension, a cluster of firms in the early phase or in the growth phase of an industry life cycle is more likely to generate higher levels of new job growth and new firm formation (e.g., regional economic development benefit) than a cluster of firms in a mature industry.

The life cycles of technologies also underlie industry growth and competitive dynamics and thus play a role in cluster-based economic development. When new technologies are developed, they can be described as competence enhancing or competence destroying (Tushman and Anderson 1986). A competence-enhancing innovation is one that relies on the same scientific and engineering base as the existing technology of incumbent firms, 


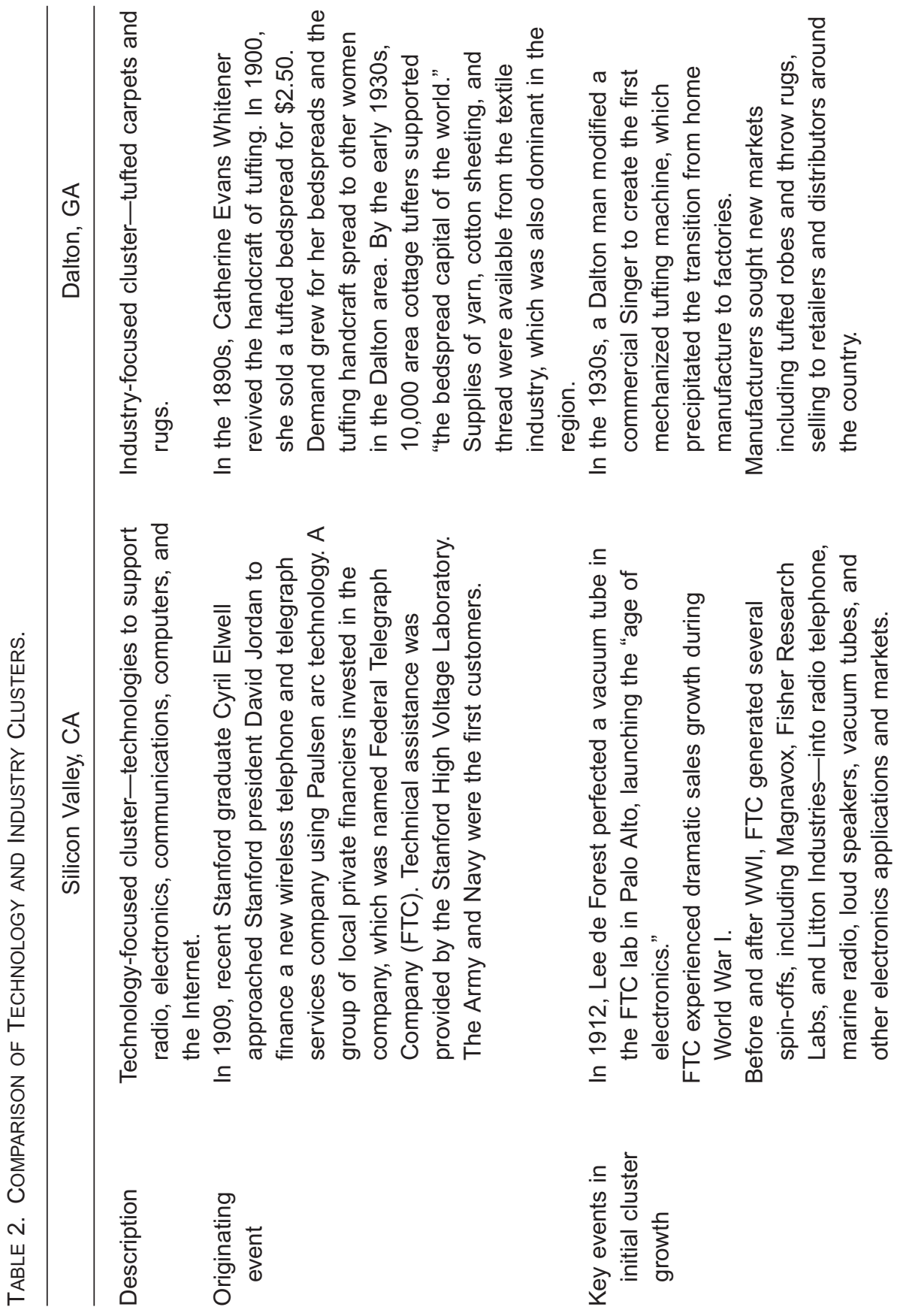




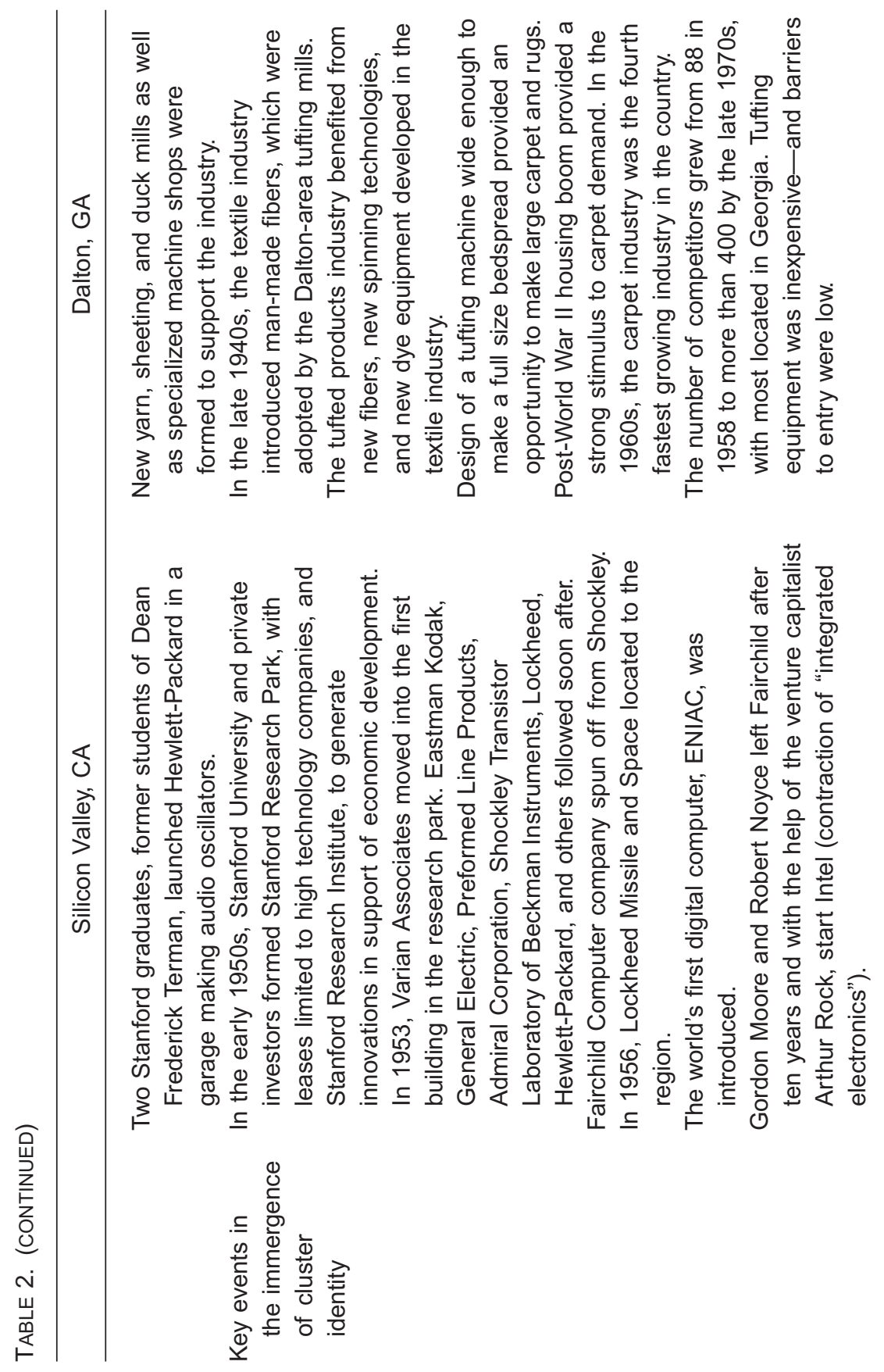




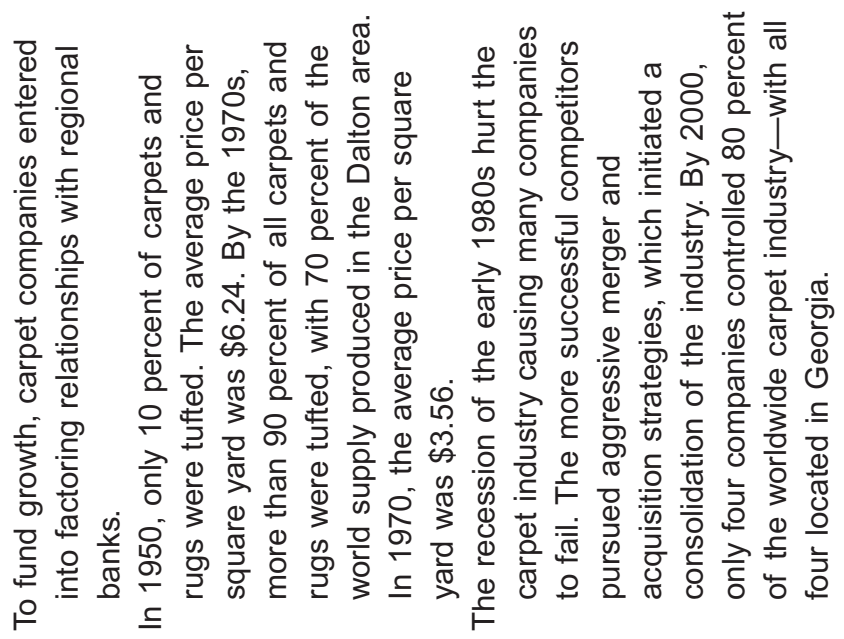

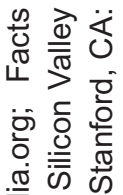

응 구웧

은

仓े ठ̀

ब्ष

힌

$\triangle 8$

过

के

ㅎํㅇ

है

善

온

雴

응

웡

出

पे

4

क्ष

बे बि के

声

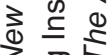

o下

Q व वें

₹

×

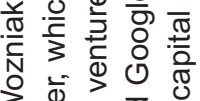

㐫 $\frac{1}{5}$ 인

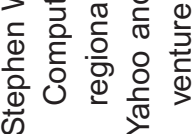

政

京紊

○心

○ 용

$\ddot{\lambda}$

की

응 응

드은?

ब

त)

๑

is

눙

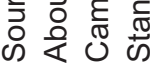


providing incumbent firms with an advantage in adopting and deploying these innovations. Competence-enhancing innovations often extend the life cycle of the existing technological base, reflected as progression along a technology "S curve" (Christensen and Rosenbloom 1995), or allow a straightforward migration path to a new technology $\mathrm{S}$ curve. Examples of competence-enhancing innovations are those many new initiatives that have led to the continuous miniaturization of silicon-based microprocessors.

In contrast, a competence-destroying technology is one that draws from different scientific and engineering competences, thus eliminating any advantage that incumbent firms might have in adopting and deploying the technology (Tushman and Anderson 1986). An example of a competence-destroying innovation is digital photography as a replacement for film photography. Competence-destroying innovations create opportunities for entry by new firms and are often the source of wholly new industries (Darby and Zucker 2003). As described by Darby and Zucker (2003: 2), "The key example of entry-generating breakthroughs are the entrepreneurial start-up phase in high-technology industries characterized by a high valuation on ability to practice the new technology while any incumbent firms' expertise in a previous technology becomes obsolete and, often, a barrier to adoption of the new technology."

Therefore, in studying clusters it is important to separate, conceptually at least, the economic development effects that are a function of the stage of the industry and technology life cycles and those that are the agglomeration and network benefits that may potentially accrue to clustered firms.

\section{Clusters and Resource Profiles}

The previous section drew a distinction between two generic cluster types: one with an industry identity and one with a technology identity. In the following sections, these generic cluster types are used as a framework for discussing how different clusters may evolve very different regional resource profiles over time, derive their growth from different industry and technology patterns, accumulate resources in a different manner, cultivate different capabilities, and develop different sources of regional advantage. In illustrating these expected differences in regional advantages, the resource-based view (Barney 1991; Wernerfelt 1984) is employed, first at the level of individuals, then at the level of firms and regions.

Individuals. The resource-based view proposes that a firm can achieve a competitive advantage through idiosyncratic resources and capabilities that have value to the market, but are not readily imitated by competitors (Barney 1991; Wernerfelt 1984). Clusters are composed of firms and individuals within those firms. In driving economic developmentjob growth, new firm formations, and wealth creation - three groups of individuals are particularly important as unique, difficult-to-imitate resources for a region: (1) researchers/ inventors, (2) entrepreneurs/managers, and (3) expert service providers including attorneys, financiers, and consultants.

Researchers and inventors. Several research studies have confirmed that new and changing technologies provide opportunities for creation of the new innovations that are 
the cornerstone of the Schumpeterian view (see Astley 1985; Brittain and Wholey 1988; Cross 1981; Dean, Meyer, and DeCastro 1993; Gould and Keeble 1984; Romanelli 1989; Tushman and Anderson 1986). Researchers and inventors that are working with new technologies operate in an environment of high uncertainty, with ambiguous choices and unclear market applications (Baum 1996; Clark 1985). For individual researchers, there is repetitive search and learning process that drives innovation and change (Brown and Eisenhardt 1995; Clark 1985) and that is characterized by adaptive learning (Van de Ven and Polley 1992). Over time, the accumulated learning, which is operating at the leading edge of a new technology and follows a path that reflects the informed choices and test-retest actions of the specific researcher, is largely unique to that researcher.

The unique scientific knowledge of the researchers coupled with their focus on earlystage technologies that have yet to reach their market potential is more likely to give rise to innovations that have the potential to create new product classes and whole new industry sectors (Darby and Zucker 2003). For example, Zucker, Darby, and Armstrong (1998) have shown that "star scientists" in bio-technology clusters contribute significantly to higher levels of innovation. Similar localized expertise in medical researchers and bioengineers in the Minneapolis medical equipment cluster have led to high rates of new medical devices such as cardiopulmonary diagnostic equipment, heart valves, and interventionary vascular devices (Lawson and Lorenz 1999). For technology clusters, then, researchers or inventors conducting basic research in a new technology area are an important idiosyncratic resource, with unique scientific knowledge that is not yet available elsewhere.

In contrast, an industry-focused cluster is more likely to track the life cycle of the industry- exhibiting the innovation patterns associated with the various stages of the life cycle (Abernathy and Utterback 1978). Although the initial start-up phase in the industry life cycle may be associated with high levels of radical innovation, as technologies and markets become more mature and better understood, research is more likely to be applied. The focus is likely to be on product or process improvements to better serve the base of existing customers, rather than creation of new product classes for uncertain, early-stage markets (Abernathy and Utterback 1978; Christensen and Rosenbloom 1995; Tushman and Anderson 1986). Many of the product and process improvements would be initiated in response to customer requests or competitor actions and would likely involve further exploitation of known technology or pursuit of competence-enhancing innovations (Tushman and Anderson 1986). Consequently, the knowledge required to develop these innovations and efficiency improvements is less likely to be localized with specific individuals, but is more widely available among the researchers in the industry. Innovations are more likely to be incremental rather than radical and in line with deep understanding of market needs. Furthermore, innovations that exploit existing technologies for known markets are more likely to exploit the existing resource base. The result is a pattern of innovations that can be implemented by existing firms and their suppliers, rather than radical innovations involving wholly new firms or new business units.

The above discussion of the proposed evolutionary paths of generic cluster types suggests that the two types of clusters may cultivate different researcher capabilities. Tech- 
nology clusters are more likely to exhibit high levels of early-stage, idiosyncratic, scientific and technical knowledge that generates inventions leading to new product classes or new industry sectors. This observation is consistent with the findings of Zhang (2003), who reports that the technical workforce in Silicon Valley reflects changes consonant with evolving core technologies. Such expertise has contributed to the region's ability to reinvent itself as technologies or products mature (Zhang 2003). For example, declines in the radio communications and consumer electronics industry were offset by growth in the aerospace industry, which was then followed by rapid growth in the computer industry (see Table 2).

In contrast, researchers in industry-focused clusters are more likely to exhibit high levels of industry-specific technical knowledge that draws on deep understanding of evolving customer needs. This type of knowledge leads to competence-enhancing innovative improvements in existing products and processes. For instance, tire manufacturers have developed significant innovations in the materials and designs of automobile tires to reduce the frequency of tire failure and improve wear life and handling. As described in Table 2, the Dalton carpet industry has drawn on technical knowledge from the regional textile industry and local equipment manufacturers to sustain improvements in tufted carpet products.

Entrepreneurs and managers. In Schumpeter's view, entrepreneurs play the pivotal role in the exploitation of innovations because they, rather than managers in established firms, recognize the opportunities presented by the new technologies (Schumpeter 1934). In developing innovations, the entrepreneur "reforms or revolutionizes the pattern of production by exploiting an invention or an untried technology for producing a new commodity or producing an old one in a new way, by opening up a new source of supply of materials, or a new outlet for products, or by reorganizing an industry" (Schumpeter 1934: 132). For managers in existing firms, the new opportunities presented by radical new technologies are so different from what they know and understand that they may fail to recognize the opportunity (Schumpeter 1934) and, even if it is recognized, they may be unwilling to reallocate resources away from existing customers into a less well-understood, more risky opportunity that is inconsistent with current industry practices and current customer needs (Christensen and Rosenbloom 1995).

Building on the ideas of Schumpeter (1934), Kirzner (1979) identified "entrepreneurial alertness" as the ability to see opportunities for new products and services, and to see new value in an existing resource. As described by Alvarez and Busenitz (2001), Kirzner (1979) distinguishes between entrepreneurial alertness and the knowledge expert (Schumpeter's inventor) in that the knowledge expert does not fully recognize the value of the knowledge or how to capitalize on it. Although the entrepreneur may not have the specialized knowledge of the technical expert, the entrepreneur's critical intangible resource is the ability to recognize an opportunity and organize a response (Alvarez and Busenitz 2001). An entrepreneur's ability to frame situations in an opportunistic manner is an idiosyncratic resource that can be difficult to imitate but that can be applied to other situations (Alvarez and Busenitz 2001). 
On the contrary, in industry-focused clusters, specialized knowledge about customers, competitors, and existing products or technologies is highly prized because it can be used to better the performance of a competitor and win share in existing markets. As noted by Pouder and St. John (1996) in describing the competitive dynamics in clustered industries, managers in clusters of competing firms are able to take advantage of close proximity to observe the innovative actions of their competitors. For example, in response to the demands of auto manufacturers and through interaction with suppliers and competitors, new product designs and manufacturing processes diffused throughout the cluster of tire manufacturers in Akron, Ohio (Sull, Tedlow, and Rosenbloom 1997). The tufted carpet industry in Dalton provides several examples of imitation propelled by direct observation. As described in Table 2, in the early 1900s, one woman's successful new business producing hand-crafted bedspreads was imitated by as many as 10,000 cottage crafters in the Dalton area. Then, after a Dalton area inventor designed relatively inexpensive machine tufting equipment, over 400 firms were formed in the same geographical area to produce tufted carpet (New Georgia Encyclopedia 2005).

Given the heightened pressure to beat known, nearby competitors, managers in industry-focused clusters may be more likely to respond to competitive cues rather than to cultivate entrepreneurial alertness as a firm-level resource and to use industry-relevant information to guide competitive choices rather than venturing into new competitive arenas. For example, in the case of the tire cluster in Akron, Ohio, the need for manufacturers to begin making radial tires was driven by exogenous demand rather than by entrepreneurial vision within the cluster (Sull, Tedlow, and Rosenbloom 1997). Even when industries undergo shocks or declines causing existing firms to downsize or shut down, the redeployed resources tend to be reallocated back to the same industry. Rosenfeld (1997) described a declining hosiery industry cluster in the Catawba Valley of western North Carolina, in which downsized employees opened small, new hosiery plants to serve niche market segments.

Service providers. In industry-focused clusters, attorneys, bankers, and other service providers develop deep knowledge about industry growth and competitive dynamics, providing a stock of expertise for firms in the industry. Through each stage of the life cycle, this deep knowledge and experience serves as a resource for clustered firms - a local resource not available in other regions. In the early stages, it helps to reduce the friction of start-up for new firms; and, in the later stages of the life cycle, it is a cluster resource that helps sustain the agglomeration economies and network effects for which clusters are known. For example, in the growth stage of the Dalton area carpet cluster, a few regional banks specialized in factoring arrangements for the industry, thereby providing working capital at critical times (New Georgia Encyclopedia 2005). In the 1990s, during an aggressive merger and acquisition phase that resulted in substantial consolidation of the carpet industry, regional service providers provided expertise in carpet industry firm valuation and negotiations.

In technology-focused clusters, attorneys, bankers, and other service providers also develop deep knowledge - but in these clusters, knowledge and expertise are more likely to be cultivated in particular technology categories. For example, venture capitalists in 
technology clusters tend to specialize by technology, limiting their investments to firms within particular technology categories, such as bio-technology, information technology, or advanced materials (Powell et al. 2002). Furthermore, in technology clusters, with the frequent formation of new firms and the creation of wholly new product categories and industries, regional experts are more likely to develop a tolerance for risk and expertise in new firm formation, which are needed to support the early stages of industry life cycles that are replicated over and over again in technology clusters.

Firm-level resources. In start-up firms, it is usually the founders who possess much of the technical and managerial expertise that create the knowledge resources of the firm (Alvarez and Busenitz 2001). In many cases, it is these knowledge resources, rather than strategic positioning, financial assets, or physical resources, that provide the advantages needed to grow and survive in an entrepreneurial climate.

Fiol (2001) has argued that sustainable competitive advantages are virtually impossible to secure in highly competitive environments. Instead, firms must continually change to create temporary advantages. In highly turbulent environments, such as those found in technology clusters, the ability to destroy and rebuild specialized resources and routines quickly and iteratively is more likely to create an advantage that provides a source of entrepreneurial rents (Fiol 2001). In this type of environment, the entrepreneur's idiosyncratic insight and the firm's ability to exploit that insight are the resources at the core of the advantage (Alvarez and Busenitz 2001). Furthermore, as the idiosyncratic insight and knowledge is inherently difficult for others to capture, it therefore contributes to the causal ambiguity that blocks imitation and secures the advantage (Barney 1991).

Drawing on Cohen and Levinthal's (1990) definition of absorptive capacity as "the ability to recognize external information, assimilate this information, and apply it to commercial ends" (128), Alvarez and Busenitz (2001) argued that an entrepreneurial firm's absorptive capacity will determine the degree to which the firm is able to appropriate entrepreneurial rents, i.e., make a profit by recognizing an opportunity and responding more quickly than competitors. Furthermore, in such dynamic environments, firms will be relatively unconstrained by path dependencies that draw from a repertoire of well-established routines (Teece, Pisano, and Shuen 1997).

In contrast, firms within an industry-focused cluster, over time, are likely to track the industry life cycle, transitioning from a more outward-focused, innovation-seeking behavior to more inward-focused, efficiency-seeking behavior (Abernathy and Utterback 1978), as markets evolve from differentiated to commodity-like. They will be attentive to competence-enhancing innovations that serve the needs of existing customers. Opportunity recognition beyond industry boundaries, of competence-destroying or disruptive innovations, will not be required for survival; therefore, these firms are less likely to cultivate entrepreneurial recognition and destroy-rebuild capabilities.

As the previous discussion illustrates, the two generic cluster types are likely to develop very different resource profiles, as summarized in Table 3 . The next section discusses the implications of these different resource profiles for regional resources, regional advantages, and economic development priorities. 
TABle 3. Differences in Characteristics of Generic TeCHnOlogy and INDUSTRY CLUSTERS.

\begin{tabular}{|c|c|c|}
\hline $\begin{array}{l}\text { Clusters and } \\
\text { characteristics }\end{array}$ & $\begin{array}{c}\text { Technology clusters such as } \\
\text { Silicon Valley, Cambridge- } \\
\text { Boston, Austin, TX, Research } \\
\text { Triangle Park, NC }\end{array}$ & $\begin{array}{l}\text { Industry clusters such as } \\
\text { Dalton, GA, carpet cluster; } \\
\text { Hickory, NC, furniture cluster; } \\
\text { Akron, OH, tire cluster; } \\
\text { Detroit, MI, auto cluster }\end{array}$ \\
\hline $\begin{array}{l}\text { Regional } \\
\text { resources }\end{array}$ & $\begin{array}{l}\text { - Inventors with idiosyncratic } \\
\text { technical knowledge } \\
\text { - Entrepreneurs with } \\
\text { idiosyncratic entrepreneurial } \\
\text { insight } \\
\text { - Accumulated } \\
\text { entrepreneurial experience } \\
\text { available through support } \\
\text { services (knowledgeable } \\
\text { attorneys, investors, other } \\
\text { service providers) } \\
\text { - Institutions such as research } \\
\text { universities, venture capital, } \\
\text { entrepreneurial networking } \\
\text { organizations, national labs or } \\
\text { large customers }\end{array}$ & $\begin{array}{l}\text { - Suppliers, distributors, } \\
\text { skilled labor } \\
\text { - Industry-specific } \\
\text { specialists, consultants, } \\
\text { service providers } \\
\text { - Institutions such as } \\
\text { trade associations }\end{array}$ \\
\hline $\begin{array}{l}\text { Source of } \\
\text { regional } \\
\text { competitive } \\
\text { advantage }\end{array}$ & $\begin{array}{l}\text { Technology transfer } \\
\text { capability in the region, } \\
\text { diversified markets and } \\
\text { applications as an outgrowth } \\
\text { of the entrepreneurial search }\end{array}$ & $\begin{array}{l}\text { - 1st and 2nd tier suppliers, } \\
\text { with related products and } \\
\text { services, reduced cost of } \\
\text { supply, reduced supply } \\
\text { uncertainty }\end{array}$ \\
\hline Growth driver & $\begin{array}{l}\text { New firm formations, spin- } \\
\text { offs from existing firms }\end{array}$ & $\begin{array}{l}\text { - New suppliers, service } \\
\text { providers, relocating or } \\
\text { new competitor facilities } \\
\text { to access available supply } \\
\text { network }\end{array}$ \\
\hline $\begin{array}{l}\text { Key regional } \\
\text { vulnerability }\end{array}$ & $\begin{array}{l}\text { - Subject to the uncertainties } \\
\text { and risk of entrepreneurial } \\
\text { boom and bust. If tied to one } \\
\text { technology, then subject to } \\
\text { that cycle. Should experience } \\
\text { more diversified demand } \\
\text { pattern. }\end{array}$ & $\begin{array}{l}\text { Subject to the demand } \\
\text { uncertainty faced by the } \\
\text { downstream firm/market. } \\
\text { Region becomes highly } \\
\text { dependent upon the } \\
\text { economic health of one } \\
\text { industry. }\end{array}$ \\
\hline $\begin{array}{l}\text { Strategic } \\
\quad \text { analogy }\end{array}$ & $\begin{array}{l}\text { Related diversification, with } \\
\text { opportunities for synergy } \\
\text { created through shared } \\
\text { resources }\end{array}$ & $\begin{array}{l}\text { Single industry concentration, } \\
\text { with some evidence of } \\
\text { vertical integration }\end{array}$ \\
\hline
\end{tabular}




\section{Cluster Evolution and Regional Advantages}

Lawson (1999) builds a compelling case for extending firm-based theories of competence to analysis of the region. He explains that "although firms and regions are not the same things, both are ensembles of competences that emerge from social interaction and so there appears to be no reason at all why the competence perspective should not be as equally relevant to the study of the region as to the study of the firm" (157-58).

Drawing on an analogy of a diversified firm (Markides and Williamson 1996), the region's performance may be superior to other regions when the combination of businesses in the region allows preferential access to the types of strategic assets that underpin the region's advantage. If a region can deploy its pool of experience, knowledge, and systems from one type of business to another, such that the cost and time to create the business is less than what it would be in other regions, the region will exhibit an advantage that is analogous to a distinctive competence in a multi-business firm (Markides and Williamson 1996; St. John and Harrison 1999). An example is the recent growth of a nanotechnology cluster in central Texas, which is exploiting the indigenous technical knowledge and entrepreneurial talents in biosciences, materials, and electronics.

Accumulated entrepreneurial experience. As described in the previous two sections, the ventures observed in technology clusters are likely to be built on idiosyncratic knowledge and insight provided by researchers and entrepreneurs, which is then appropriated by firms via high levels of absorptive capacity (a firm-level resource) and entrepreneurial rentseeking (destroy-rebuild strategies). Firms in technology clusters have access to other difficult-to-imitate resources, as well. Building on additional experience, entrepreneurs learn to better adapt to changing conditions and to discover whether they have the "right stuff" (Stephan 1996). Over time, entrepreneurial experience can be accumulated as a regional resource that individuals and firms in the region may draw on (Shane 1996).

The accumulated entrepreneurial experience, embedded in the knowledge of local entrepreneurs, venture capitalists, attorneys, and other service providers, creates a stock of knowledge that has value to subsequent entrepreneurial ventures. A region's accumulated entrepreneurial experience serves as a stimulus to entrepreneurial activity in subsequent periods (Shane 1996). Entrepreneurial successes are associated with increased rates of entrepreneurial activity because of the legitimacy that is created for entrepreneurship and the opportunities for imitating successful entrepreneurs (see Aldrich and Fiol 1994; Hannan and Freeman 1984; Romanelli and Schoonhoven 2001; Shane 1996). Accumulated entrepreneurial experience can also increase the speed and success of new venture launch. As with multibusiness firms, the experience gained in building one business can be used to reduce the friction of building similar resources in other new businesses (Markides and Williamson 1996), thereby reducing the cost and time to launch new ventures and improving the likelihood of screening out weak venture concepts.

In contrast, for firms in industry-focused clusters, the attorneys, investment bankers, and service providers are more likely to accumulate industry-relevant experiences that are valuable in forming new industry-related ventures and enhancing productivity of industry firms - rather than insight and comfort with the creation of new ventures to exploit uncer- 
tain technologies and ill-defined markets. These experiences will frame mental models that reinforce perspectives toward risk-taking and uncertainty (Porac, Thomas, and BadenFuller 1989). Consequently, compared to industry-focused clusters, technology clusters are more likely to accumulate entrepreneurial experience as a regional resource that stimulates subsequent entrepreneurial activity, reduces the cost and time of launching new ventures, reinforces attitudes toward risk, and serves to screen out weak venture concepts. Industry-focused clusters, on the other hand, are more likely to cultivate industry-specific experience and knowledge, which serve as the keystone of the cluster's agglomeration economies.

Regional networks. The pattern and content of interactions that take place between groups, referred to as social networks, are an important characteristic of clusters. Deeds, DeCarolis, and Coombs (2000) showed that proximity in bio-technology clusters promotes enhanced transfer of knowledge as a consequence of more natural exchange of ideas through formal and informal networks. As described by Gnyawali and Madhavan (2001), a superior position in the network of cooperative relations translates into a resource advantage and an increased likelihood of competitive action. McEvily and Zaheer (1999) explored the social, professional, and economic networks of a geographical cluster and the relationship of networks to firm-level competitive capabilities. They noted that firms within a cluster are more likely to achieve face-to-face interaction and more frequent interaction, both of which increase the value of the network tie.

As described by Granovetter (1973), strong network ties are created through a high degree of closeness and reciprocal action. Weak ties connect individuals with others outside the group, analogous to casual acquaintances (Granovetter 1973). Strong ties, such as those exhibited in buyer-supplier relationships, are more likely to lead to sharing of sensitive information, whereas weak ties, such as those exhibited among members of a professional society or regional economic development group, are more likely to provide access to a great amount and diversity of information. Strong ties are more likely to be valuable in reducing perceived uncertainty and information asymmetry (Uzzi 1997) and to establish links to critical resources during the early stages of new venture growth (Starr and MacMillan 1990). However, the more weak ties an individual has in his or her network, the more valuable the network is as a source of information (Podolny and Baron 1997). Weak ties provide more diverse and richer links to the kinds of novel and unique information that may be needed to generate innovative activity (Granovetter 1973; Johannessen, Olsen, and Lumpkin 2001; O'Donnell et al. 2001). According to Patrucco (2003:162), ". . . based on a network of communication channels, learning by interacting emerges as the crucial mechanism to effectively build up the collective character of knowledge, in turn ensuring innovation."

Both industry clusters and technology clusters are likely to take advantage of the proximate connectivity available through networks; however, they are likely to do so in different ways. In promoting market-driven economic efficiency and effectiveness, clustered firms within the same industry are likely to structure formal, tightly coupled, and wellspecified network relationships, including those with suppliers, attorneys, and bankers. In 
contrast, the innovation processes in technology clusters are likely to be much less predictable, largely intangible, and drawn from a transitory pool of resources distributed across a range of firms (and universities) within the cluster, with weak network ties serving as a key mechanism for acquiring that information. Where multiple technological trajectories coexist and move at different rates and in different directions, the sharing and/or diffusion of knowledge will tend to be more spontaneous and serendipitous. Crossindustry innovations can be better recognized and exploited in technology clusters that cut across industry boundaries, such as emergence of biophotonics at the intersection of photonics and bioscience technologies. Such innovations result from the fusion of different technologies rather than the emergence of discrete breakthroughs in a single technology (Kodama 1995).

In technology clusters, the region's accumulated entrepreneurial experience and idiosyncratic knowledge may be accessed through both strong ties (e.g., relationships with bankers, attorneys) and weak ties (e.g., referrals to venture capital firms, entrepreneurial networking events, information about resource availability or new technologies). Furthermore, in technology clusters, weak ties may allow firms access to informal social relationships (Camagni 1991), regionally mobile individuals, teams with knowledge that is not easily codified (Keeble, et al. 1996), and sociocultural and socioeconomic webs of common conventions and understanding (Storper 1995). Access to idiosyncratic technical know-how "takes place through informal interchange of information between firms signaling, for example, various successful decisions or reputation" (Lawson 1999: 159).

Sustaining advantage over time. Technology clusters may be regarded as drivers of enhanced synergy and value creation. As with mergers and acquisitions among firms, value creation and the ability to achieve a competitive advantage is greater in the union of firms having different resources rather than similar resources because the synergistic relationship is unique, potentially complementary, and not easily imitated (Barney 1986). This suggests that the technology cluster may be considered as a unique accumulation of different value-creating resources whose union creates synergy and provides the technology cluster with an advantage in the ability to give birth to new firms and completely new industries.

As firm-level competences are associated with bundles of resources and capabilities, so too are the "ensembles of competences" of regional production systems (Lawson 1999). Drawing on the resource-based view of the firm, Foss (1996) proposes that geographically bounded groups of firms are sources of rent-yielding, shared nonproprietary and intangible resources and capabilities. Furthermore, through interdependencies accessed through networks, such as standards, shared research and development knowledge, and common social norms, these groups are able to sustain the rent-yielding potential and thus the competitive advantage of the region (Foss 1996).

A key point implicit in the ability to sustain competitive advantage is that it persists over time. Because industry clusters and technology clusters have different stocks and flows of resources and capabilities, they will likely differ in their ability to build a sustained competitive advantage. In the case of industry clusters, the resources and capabil- 
ities will likely be relatively predictable as the industry follows the trajectory of its industry life cycle, manifesting the typical patterns of innovative behavior associated with each stage (Abernathy and Utterback 1978). Industry clusters may be able to sustain a competitive advantage over time because of having resources and capabilities that are unique to the cluster and difficult for competitors outside the cluster to imitate, such as coal in proximity to a steel cluster.

On the other hand, industry clusters may be more vulnerable to exogenous forces, such as the emergence of completely new technologies that render an industry's products or resource advantage obsolete (e.g., mini-mills making coal unnecessary for steel production) or the dominance of foreign competitors (e.g., American auto companies and Detroit). Examples of the latter include the cluster of furniture manufacturers in western North Carolina (Rosenfeld 1997) and the cluster of textile manufacturers in South Carolina (Stone 2005). Being industry-focused and lacking the technical and entrepreneurial capabilities that create recombinatorial opportunities for the region, these clusters are disappearing in the wake of foreign competition.

Rather than focusing on a single industry, technology clusters have an opportunity to sustain competitive advantage across a set of existing and emergent industries. The recombinatorial opportunities associated with its broad knowledge base and entrepreneurial alertness provide technology clusters with capabilities that have an opportunity to persist over time. As one technology matures or obsolesces, a new one emerges. From a resource-based view, the cluster consists of dynamic flows of interconnected resource stocks from which new resource stocks are accumulated over time (Dierickx and Cool 1989) and provide the basis for technological breakthroughs. For example, Silicon Valley's embedded technical and entrepreneurial knowledge provided a basis for the development of vacuum tubes, followed by transistors, and, later, semiconductors.

Given the capabilities that are nurtured in technology clusters, it is likely that they are better equipped to endure and respond to exogenous shocks over time. Consider the high technology cluster in the greater Boston area and the rapid rise and fall of minicomputer technologies during the 1980s (Saxenian 1994). Many minicomputer firms in the cluster disappeared as the microcomputer became the dominant technology. However, over time, the region has developed a sustained competitive advantage in related technologies that focus on networking gear and specialized peripheral computer equipment. In the presence of rejuvenating combinations of resources not only in computers, but also in a wide array of complementary technologies, the cluster will likely sustain its competitive advantage well into the future.

\section{Discussion and Implications}

This article distinguishes between two generic types of clusters, those that evolve an industry focus and those that are more closely associated with new technology development. By viewing each cluster type through the theoretical lens of the resource-based view, it is possible to offer several observations about key differences between cluster types and the implications of those differences for the accumulated regional resources as well as the 
types of economic activity conducted in the cluster. Table 4 summarizes these concepts with an application to Silicon Valley and the Dalton, Georgia, carpet industry cluster.

In 2001, the Council on Competitiveness (2001) noted that the extraordinary growth in the U.S. economy during the 1990s was the result of the national ability to develop innovative new businesses from new technologies and inventions. Between 1990 and 2000, the U.S. economy created 15 million new jobs, with over one-third of the new jobs created by the roughly 6.4 million new firms formed during those same years (U.S. Small Business Administration 2001). Overall, 75 percent of new jobs were created by new and expanding small firms in the country. As pointed out by the Council on Competitiveness (2001), however, the majority of those jobs were created in a select few entrepreneurial regions of the country. Because of these observations, the council recommended that the nation employ clustering strategies in other regions of the country, with the expectation that these regional clusters would give rise to innovative new firms.

In this article, clusters have been described as of two generic types: (1) industry focused, in which the cluster evolves over time in line with the industry life cycle, and (2) technology focused, in which new technologies give rise to new product classes and whole new industries. Industry-focused clusters, on the one hand, develop deep expertise in the industry of interest. Key resources include skilled labor, technical and scientific personnel with industry-specific knowledge pertaining to technology and markets, specialized business service providers (e.g., bankers, attorneys, accountants) with in-depth knowledge of the industry, and strong network ties that bind together specific groups. These resources provide the cluster with unique, synergistic advantages for those firms that choose to locate there. It reduces the friction of doing business. Industry-based clusters tie the fortunes of the region to the economic cycle of one industry and are analogous to a single business or vertically integrated business - all assets concentrated on the demand provided by one industry.

In contrast, technology clusters include key resources such as idiosyncratic technological discovery, idiosyncratic entrepreneurial insight, accumulated entrepreneurial experience, and both strong network ties for accessing resources essential for survival and weak network ties for accessing information that is critical to the innovative process. These idiosyncratic technological and entrepreneurial resources are not as available or highly sought in industry clusters because industry clusters do not need to build the skill sets to develop and exploit strong recombinatorial capabilities. Technology clusters focus on early stage technologies and emerging markets, and have an opportunity to continually generate and reposition firms in the growth phase of various industry life cycles. Over time, these clusters may evolve a lateral structure in which the number of industries represented in the cluster increases. By analogy, technology clusters will be like a firm that participates in related diversified businesses.

Because geographic clusters have recently received much scholarly attention and have become the locus of much effort in economic development, substantial work lies ahead for researchers and practitioners. By using the two types of clusters proposed in this article, research could be conducted with less conceptual ambiguity and greater methodological 
table 4. Regional Resource Profiles and Cluster Evolution.

\begin{tabular}{|c|c|c|}
\hline & Silicon Valley, CA & Dalton, GA \\
\hline \multicolumn{3}{|l|}{ Resources } \\
\hline Individuals & $\begin{array}{l}\text { Individual inventors and } \\
\text { researchers creating new } \\
\text { technologies that are the } \\
\text { foundation for emerging } \\
\text { electronics, computer, and } \\
\text { internet communications } \\
\text { industries. Idiosyncratic } \\
\text { knowledge leading to new } \\
\text { product classes and completely } \\
\text { new industries. } \\
\text { Individual investors that } \\
\text { recognize opportunities and } \\
\text { support new start-ups and } \\
\text { regional economic development } \\
\text { initiatives } \\
\text { Insightful academic administrators } \\
\text { who recognize opportunities } \\
\text { and see the value of } \\
\text { partnerships between the } \\
\text { university and high technology } \\
\text { companies in the region. }\end{array}$ & $\begin{array}{l}\text { Specialized knowledge } \\
\text { derived largely from the } \\
\text { textile industry, including } \\
\text { knowledge about tufting } \\
\text { equipment, synthetic } \\
\text { fibers, dyeing } \\
\text { technology. } \\
\text { Most innovations focused } \\
\text { on extending product } \\
\text { lines within the tufted } \\
\text { carpet industry and } \\
\text { driving down costs. } \\
\text { Local bankers, most } \\
\text { notably Trust Company } \\
\text { of Georgia and C\&S } \\
\text { Bank, provide capital to } \\
\text { the carpet companies, } \\
\text { through factoring } \\
\text { relationships. } \\
\text { In recent years, the } \\
\text { Dalton-area carpet } \\
\text { industry has relied on } \\
\text { Hispanic immigrants to } \\
\text { keep labor costs low. }\end{array}$ \\
\hline Firms & $\begin{array}{l}\text { Spin-off firms take technology } \\
\text { into wholly new markets and } \\
\text { industries }\end{array}$ & $\begin{array}{l}\text { Firms track the industry } \\
\text { life cycle through } \\
\text { growth stage to maturity } \\
\text { and consolidation }\end{array}$ \\
\hline Regional & $\begin{array}{l}\text { Accumulated entrepreneurial } \\
\text { experience, comfort with the } \\
\text { risks and rewards of radical } \\
\text { innovation, rich availability of } \\
\text { risk capital, service providers } \\
\text { experienced in electronics and } \\
\text { computing technology markets. } \\
\text { Entrepreneurial networks. }\end{array}$ & $\begin{array}{l}\text { Textile industry } \\
\text { resources and supply } \\
\text { network, including fiber } \\
\text { producers, equipment } \\
\text { producers, specialized } \\
\text { machine shops, dyeing } \\
\text { experts-all available to } \\
\text { tufted carpet industry. } \\
\text { Strong industry trade } \\
\text { association. }\end{array}$ \\
\hline
\end{tabular}


TABLE 4. (CONTINUED)

\begin{tabular}{|c|c|c|}
\hline & Silicon Valley, CA & Dalton, GA \\
\hline $\begin{array}{l}\text { Key } \\
\quad \text { vulnerabilities }\end{array}$ & $\begin{array}{l}\text { When the economy is poor, } \\
\text { investors may be more likely to } \\
\text { invest in less risky ventures. }\end{array}$ & $\begin{array}{l}\text { Changes in customer } \\
\text { preferences away from } \\
\text { tufted carpet. } \\
\text { Creation of a new } \\
\text { technology that } \\
\text { displaces tufting } \\
\text { technology. }\end{array}$ \\
\hline $\begin{array}{l}\text { Fit with } \\
\text { strategy } \\
\text { analogy }\end{array}$ & $\begin{array}{l}\text { Through significant radical } \\
\text { inventions (vacuum tube, } \\
\text { transistor, semiconductor, } \\
\text { mainframe computer, personal } \\
\text { computer, search engines, etc.) } \\
\text { the Silicon Valley region has } \\
\text { participated in the growth phases } \\
\text { of several new industries-(1) } \\
\text { radio, telephone, telegraph, }(2) \\
\text { electronics, (3) semiconductors } \\
\text { and computers, (4) personal } \\
\text { computers, and (5) internet and } \\
\text { communications. } \\
\text { Regional diversification. }\end{array}$ & $\begin{array}{l}\text { One industry: tufted } \\
\text { carpet. } \\
\text { Demand is tied to } \\
\text { residential housing } \\
\text { starts and commercial } \\
\text { sector growth. } \\
\text { At the mature phase, } \\
\text { emphasis is on } \\
\text { efficiency and cost } \\
\text { savings and, most } \\
\text { recently, industry } \\
\text { consolidation. } \\
\text { Companies tracking } \\
\text { industry life cycle. }\end{array}$ \\
\hline
\end{tabular}

precision, while providing economic developers with a more precise framework for planning, establishing, and evaluating geographic clusters.

These ideas need to be tested empirically. For instance, researchers could conduct longitudinal studies of the recombinatorial characteristics of each cluster type. As proposed in this article, do new product types or new industry types appear more frequently in technology clusters than in industry clusters? And, if so, are there differences in the breadth of unique knowledge among researchers and entrepreneurs in each cluster type? Researchers in entrepreneurship could investigate differences in the frequency of new firm formation in the two types of clusters, and could determine the propensity of firms in technology clusters to form around unique technical knowledge. In addition, researchers could investigate differences in the capabilities provided by entrepreneurs in the two clusters. For instance, do entrepreneurial alertness and entrepreneurial responsiveness differ in cluster types? Researchers in networks could extend ongoing work in the area of social networks and examine the relative importance of strong and weak ties over time, and the 
degree to which industry-focused and knowledge-based clusters differ in their reliance on weak ties to stimulate innovation and entrepreneurial activity.

Researchers and practitioners could draw from various quantitative and qualitative methods to conduct empirical tests. To date, most research identifying clusters has relied on qualitative methods such as interviews and surveys targeted for individuals having strong knowledge of the regional economy. For example, Hendry, Brown, and DeFillippi (2000) conducted interviews with opto-electronics firms to determine the pattern, origin, and value of network connections to other firms, research organizations, and development agencies. In a study of British communications firms, Oakley, Kipling, and Wildgust (2001) used surveys to identify clusters and the business linkages of clusters at regional and local levels. Other qualitative sources that could be used in cluster identification include information published in newspapers, regional and industry association newsletters, and company documents and press releases.

Although often subject to limitations in quality and availability of data, quantitative techniques may help identify clusters. For example, some researchers have used input-output analysis. Following techniques prescribed by Feser and Bergman (2000), information on national, interindustry, input-output production flow linkages can be used to provide templates for detecting and describing clusters at the regional level. More sophisticated methods of cluster analysis using regional input-output data were used recently by Oosterhaven, Eding, and Stelder (2001) to identify clusters and their interrelationships in three Dutch regions. Input-output analysis based on survey-derived innovation interactions is another technique that might be used to identify clusters (see DeBresson 1996). A related approach to identifying clusters would use input-output data or qualitative data in a network analysis framework similar to techniques used to study social networks (Feser and Bergman 2000). Perhaps most fruitful in future efforts to identify clusters will be those that combine qualitative and quantitative techniques. For instance, input-output measures of clusters could be strengthened by survey, printed, and interview information that provides insight into actual interorganizational linkages and perceptual measures of their relative importance.

The formal and informal ties that cohere firms in clusters raise interesting questions that could be examined using nontraditional applications of management and organization theory. For instance, Porter (1998) notes that "the geographically proximate cluster of independent and informally linked firms and institutions represents a robust organizational form in the continuum between markets and hierarchies-but one still little explored in theory. Location can powerfully shape tradeoffs between markets and hierarchies" (223). Researchers responding to this notion could invoke transaction cost theory as a platform for investigating not only the tradeoffs between markets and hierarchies, but also the degree to which such tradeoffs might differ according to cluster type. For instance, in line with the notion of hybrid governance structures (Hennart 1993; Williamson 1991), industry clusters may align more closely with a hierarchical form whereas technology clusters may be more closely associated with a market form. Other interesting studies could extend arguments for a resource-based view 
of the region (Lawson 1999), but draw additional distinctions between technology and industry cluster settings.

These ideas should have strong practical implications. In particular, policy makers may be interested in the distinctions between technology and industry clusters, and may be even more interested if these distinctions can be confirmed empirically. Certainly both types of clusters offer regional economic development benefits - but the regional resources that are cultivated over time differ substantially, with the economic development impacts evolving from different modes of growth. As proposed in this article, industry-focused clusters develop a form of specialization that improves efficiency and provides for agglomeration economies, providing tangible benefits for locating in the clusters (Scott 1992). Over time, however, that specialization concentrates the fortunes of the region on one industry life cycle, as with the auto industry in the Detroit region, the furniture industry in North Carolina, the carpet industry in Georgia, and the steel industry in Pennsylvania. An industry cluster very effectively and efficiently evolves the capabilities needed at each stage of the industry life cycle, moving from a focus on innovation to a focus on efficiency, analogous to the innovation behavior of firms as they track the industry life (Abernathy and Utterback 1978). As long as the industry is stable, these efficiencies are a source of advantage for firms in the cluster (Pouder and St. John 1996). When the industry moves to the end of its life cycle or experiences a shock, firms in the cluster, having had no motivation to develop the entrepreneurial infrastructure needed to participate in early-stage ventures and therefore having no new leading-edge technological knowledge, lack the unique resources and the recombinatorial ability needed to reorient.

Technology clusters are more closely tied to the early stages of industry life cyclesand they cultivate resources, at both the firm and regional levels, that can support rapid growth and innovation. Over time, however, technology clusters are less likely to be the site of mature, more efficient industries. Silicon Valley is, after all, a net job exporter for this reason (Zhang 2003). Large scale manufacturing, for example, may be incompatible with the skills and cost structure afforded by a technology cluster.

What are the implications for public policy officials? As described by Bergman and Feser (1999), "From a policy point of view, knowing what could become a cluster (perhaps with proper policy stimulation) is frequently more critical than knowing what is a cluster. Indeed, the latter may be obvious more often than not." For regions that are interested in employment for workers displaced by the off-shoring of traditional manufacturing jobs and declines in farming employment, pursuit of what has here been called a "technology cluster" is unlikely to be a successful mechanism for creating jobs in the region. The unique combination of idiosyncratic technical knowledge, entrepreneurial mindset of individuals, and accumulated entrepreneurial experience observed in the existing technology clusters does not exist in most regions and could take decades to cultivate, if it can be deliberately cultivated at all. Instead, these regions could attempt to seed an industry cluster through recruitment of a large employer, particularly one that is likely to attract large numbers of suppliers and service providers to the surrounding area. This "buffalo hunting" approach, which is often criticized in the knowledge economy age, is a mechanism for catalyzing the formation of an industry 
cluster. For example, recruitment of an auto assembly plant can stimulate relocation of auto suppliers to the region. Over time, the region can benefit from the growth of an auto-supply cluster. However, as noted, with concentration of same-industry suppliers, the region will be vulnerable to the economic cycles of the industry, something policy officials would need to plan for by actively diversifying the base of companies in the region.

For regions with one or more very strong research universities, where a high quality of life encourages graduates and successful, imaginative business people to stay in the region, an opportunity may exist to stimulate the formation of a technology cluster. In these cases, the focus should be on cultivating social ties between exceptional faculty researchers, creative graduate students, and active entrepreneurial business people - with an understanding that inventiveness and entrepreneurial insight are characteristics of individuals - not regions - and they are easy to recognize but hard to find.

\section{REFERENCES}

Abernathy, W. J., and J. M. Utterback. 1978. Patterns of industrial innovation. Technology Review 80(7): 40-47.

Aldrich, H. E., and C. M. Fiol. 1994. Fools rush in? The institutional context of industry creation. Academy of Management Review 19: 645-670.

Alvarez, S. A., and L. W. Busenitz. 2001. The entrepreneurship of resource-based theory. Journal of Management 27: 755-775.

Antonelli, C. 2000. Collective knowledge communication and innovation: The evidence of technological districts. Regional Studies 34: 535-547.

Archer, K. 1997. The limits of imagineered city: Sociospatial polarization in Orlando. Economic Geography 73: 322-336.

Astley, W. G. 1985. The two ecologies: Population and community perspectives on organizational evolution. Administrative Science Quarterly 30: 224-241.

Audretsch, D. B., and M. P. Feldman. 1996. R\&D spillovers and the geography of innovation and production. American Economic Review 86: 630-640.

Barney, J. B. 1986. Strategic factor markets. Management Science 42: 1231-1241.

. 1991. Firm resources and sustained competitive advantage. Journal of Management 17: 99-120.

Baum, J. A. C. 1996. Organizational ecology, organizations, technology, and structuring. In Handbook of organization studies, ed. S. R. Clegg, W. R. Hardy, and W. R. Nord, 77-114. London: Sage.

Bergman, E. M., and E. J. Feser. 1999. Industrial and regional clusters: Concepts and comparative applications. The web book of regional science. Regional Research Institute. West Virginia University. http://www.rri.wvu.edu/WebBook/Bergman-Feser/Contents.htm (accessed fall, 2005)

Bresnahan, T. A., A. Gambardella, and A. Saxenian. 2001. Old economy inputs for new economy outputs: Cluster formation in the new Silicon Valleys. Industrial and Corporate Change 10: 817-833.

Brittain, J. W., and D. R. Wholey. 1988. Competition and coexistence in organizational communities: Population dynamics in electronic components manufacturing. In Ecological models of organisations, ed. G. R. Carroll, 195-222. Cambridge, MA: Ballinger. 
Brown., S. L., and K. M. Eisenhardt. 1995. Product development: Past research, present findings, and future directions. Academy of Management Review 20: 343-378.

Camagni, R. 1991. Local milieu, uncertainty and innovation networks: Towards a new dynamic theory of economic space. In Innovation Networks: Spatial Perspectives, ed. R. Camagni, 121-142. London: Belhaven Press.

Carron, C. G. 1998. Grand Rapids furniture: The story of America's furniture city. Traverse City, MI: Village Press.

Christensen, C. M., and R. S. Rosenbloom. 1995. Explaining the attacker's advantage: Technological paradigms, organizational dynamics, and the value network. Research Policy 24: 233-257.

Clark, K. B. 1985. The interaction of design hierarchies and market concepts in technological evolution. Research Policy 14: 235-251.

Cohen, W. M., and D. A. Levinthal. 1990. Absorptive capacity: A new perspective on learning and innovation. Administrative Science Quarterly 35: 128-152.

Connecticut Maritime Coalition. 2000. Strategic cluster initiative: Linking Connecticut's future with the emerging global trade grid. New London, CT: Connecticut Maritime Coalition.

Cortright, J., and H. Mayer. 2002. Signs of life: The growth of biotechnology centers in the U.S. Washington, DC: The Brookings Institution Center for Urban and Metropolitan Policy.

Council on Competitiveness. 2001. U.S. competitiveness 2001: Strengths, vulnerabilities and longterm priorities. Washington, DC: Council on Competitiveness.

Cross, M. 1981. New firm formation and regional development. Farnborough, UK: Gower.

Darby, M. R., and L. G. Zucker. 2003. Growing by leaps and inches: Creative destruction, real cost reduction, and inching up. Economic Inquiry 41: 1-18.

DeBresson, C. 1996. Economic interdependence and economic activity. Cheltenham, UK: Edward Elgar.

Dean, T., G. Meyer, and J. DeCastro. 1993. Determinants of new firm foundation in manufacturing industries: Industry dynamics, entry barriers, and organizational inertia. Entrepreneurship Theory and Practice 18: 49-60.

Deeds, D. L., D. DeCarolis, and J. Coombs. 2000. Dynamic capabilities and new product development in high technology ventures: An empirical analysis of new biotechnology firms. Journal of Business Venturing 15: 211-229.

Dierickx, I., and K. Cool. 1989. Asset stock accumulation and sustainability of competitive advantage. Management Science 35: 1504-1511.

The Economist. 2002. Is the sun rising in the East at last? December 12, 365.

Enright, M. J. 1996. Regional clusters and economic development: A research agenda. In Business networks: Prospects for regional development, ed. U. Staber, N. Schaefer, and B. Sharma, 190-214. Berlin: Walter de Gruyter.

"History of Carpet". 2005. Facts about the carpet industry, Carpet and Rug Institute. http://www.carpetrug.com (accessed fall, 2005).

Feldman, M. P., and D. B. Audretsch. 1999. Innovation in cities: Science-based diversity, specialization, and localized competition. European Economicreview 43: 409-429.

Ferguson, T. W. 1999. Sun, fun, and Ph.Ds, too. Forbes, May 31, 163.

Feser, E. J., and E. M. Bergman. 2000. National cluster templates: A framework for applied regional cluster analysis. Regional Studies 34: 1-19.

Fiol, M. 2001. Revisiting an identity-based view of sustainable competitive advantage. Journal of Management 6: 691-699. 
Foss, N. J. 1996. Higher-order industrial capabilities and competitive advantage. Journal of Industry Studies 3: 1-20.

Gnyawali, D. R., and R. Madhavan. 2001. Cooperative networks and competitive dynamics: A structural embeddedness perspective. Academy of Management Review 26: 431-445.

Gold, R. 2001. Cities pursue benefits of clusters-A concentration of firms in one seen spurring jobs, growth. Wall Street Journal June 6, B11.

Gould, A., and D. Keeble. 1984. New firms and rural industrialization in East Anglia. Regional Studies 18: 189-201.

Granovetter, M. S. 1973. The strength of weak ties. American Journal of Sociology 6: 1360-1380.

Hannan, M. J., and G. Freeman. 1984. Structural inertia and organizational change. American Sociological Review 49: 149-164.

Harrison, B. 1992. Industrial districts: Old wine in new bottles? Regional Studies 26: 469-483.

Hendry, C., J. Brown, and R. DeFillippi. 2000. Regional clustering of high technology-based firms: Opto-electronics in three countries. Regional Studies 34: 129-144.

Hennart, J. 1993. Explaining the swollen middle: Why most transactions are a mix of market and hierarchy. Organization Science 4: 529-547.

Jacobs, D., and A. P. de Man. 1996. Clusters, industrial policy and firm strategy: A menu approach. Technology Analysis \& Strategic Management 8: 425-437.

Johannessen, J. A., B. Olsen, and G. T. Lumpkin. 2001. Innovation as newness: What is new, how new, and new to whom? European Journal of Innovation Management 4: 20-31.

Keeble, D., C. Lawson, B. Moore, and F. Wilkinson. 1996. Collective learning processes, networking and "institutional thickness" in the Cambridge Region. Regional Studies 33: 319-332.

Keeble, D., and F. Wilkinson. 1999. Collective learning and knowledge development in the evolution of regional clusters of high technology SMEs in Europe. Regional Studies 33: 295-303.

Kirzner, I. 1979. Perception, opportunity, and profit. Chicago, IL: University of Chicago Press.

Kodama, F. 1995. Emerging patterns of innovation: Sources of Japan's technological edge. Cambridge, MA: Harvard Business School.

Krugman, P. 1995. Development, geography, and economic theory. Cambridge: MIT Press.

Lawson, C. 1999. Towards a competence theory of the region. Cambridge Journal of Economics 23: $151-166$.

Lawson, C., and E. Lorenz. 1999. Collective learning, tacit knowledge and regional innovative capacity. Regional Studies 33: 305-317.

Maarten de Vet, J., and A. J. Scott. 1992. The southern California medical device industry: Innovation, new firm formation, and location. Research Policy 21: 145-161.

Maillat, D. 1991. The innovation process and the role of the milieu. In Regions reconsidered: Economic networks, innovation, and local development, ed. E. Bergman, G. Maier, and F. Todtling. London: Mansell.

Markides, C. C., and P. J. Williamson. 1996. Corporate diversification and organizational structure: A resource-based view. Academy of Management Journal 39: 340-367.

Marshall, A. 1920. Principles of economics. London: MacMillan.

Maskell, P. 2001. Towards a knowledge-based theory of the geographical cluster. Industrial and Corporate Change 10: 921-943.

McEvily, B., and A. Zaheer. 1999. Bridging ties: A source of firm heterogeneity in competitive capabilities. Strategic Management Journal 20: 1133-1156. 
Moulaert, F., and F. Sekia. 2003. Territorial innovation models: A critical survey. Regional Studies 37: 289-302.

The New Georgia Encyclopedia. 2005. Carpet industry: overview, The New Georgia Encyclopedia: http://www.newgeorgiaencyclopedia.org (accessed fall, 2005).

Newlands, D. 2003. Competition and cooperation in industrial clusters: The implications for public policy. European Planning Studies 11: 521-532.

Oakley, R., M. Kipling, and S. Wildgust. 2001. Clustering among firms in the non-broadcast visual communications (NBVC) sector. Regional Studies 35: 401-414.

Oosterhaven, J., G. J. Eding, and D. Stelder. 2001. Clusters, linkages and interregional spillovers: Methodology and policy implications for two Dutch mainports and the rural north. Regional Studies 35: 809-822.

O'Donnell, A., D. Gilmore, D. Cummins, and D. Carson. 2001. The network construct in entrepreneurship research: A review and critique. Management Decision 39: 749-760.

Patrucco, P. P. 2003. Institutional variety, networking, and knowledge exchange: Communication and innovation in the case of the Brianza technological district. Regional. Science 37: 159-172.

Podolny, J. M., and J. N. Baron. 1997. Relationships and resources: Social networks and mobility in the workplace. American Sociological Review 62: 673-693.

Porac, J. F., H. Thomas, and C. Baden-Fuller. 1989. Competitive groups as cognitive communities: The case of Scottish knitwear manufacturers. Journal of Management Studies 26: 397-416.

Porter, M. E. 1998. On competition. Boston: Harvard Business School Press.

Porter, M. E., and D. van Opstal. 2000. U.S. competitiveness 2001: Strengths, vulnerabilities, and long term priorities. Washington, DC: Council on Competitiveness.

Pouder, R., and C. H. St. John. 1996. Hot spots and blind spots: Geographical clusters of firms and innovation. Academy of Management Review 21: 1192-1225.

Powell, W. W., K. W. Koput, J. I. Bowie, and L. Smith-Doerr. 2002. The spatial clustering of science and capital: Accounting for biotech firm-venture capital relationships. Regional Studies 36: 291-305.

Rauch, J. E. 1993. Does history matter only when it matters little? The case of city-industry location. The Quarterly Journal of Economics 108: 843-867.

Romanelli, E. 1989. Environments and strategies of organizational start-up: Effects on early survival. Administrative Science Quarterly 34: 369-387.

Romanelli, E., and C. B. Schoonhoven. 2001. The local origins of new firms. In The entrepreneurship dynamic: Origins of entrepreneurship and the evolution of industries, ed. C. B. Schoonhoven and E. Romanelli, 40-67. Stanford, CA: Stanford University Press.

Rosenfeld, S. A. 1997. Bringing business clusters into the mainstream of economic development. European Planning Studies 5: 2-23.

Saxenian, A. 1994. Culture and competition in Silicon Valley and Route 128. Cambridge, MA: Harvard University Press.

Schumpeter, J. 1934. The theory of economic development. Cambridge, MA: Harvard University Press.

Scott, A. J. 1989. New industrial spaces: Flexible production organization and regional development in North America and Western Europe. London: Pion Ltd.

1992. The Roepke lecture in economic geography: The collective order of flexible production agglomerations: Lessons for local economic development policy and strategic choice. Economic Geography 68: 219-233. 
Shane, S. 1996. Explaining variation in rates of entrepreneurship in the United States: 1899-1988. Journal of Management 22: 747-781.

St. John, J. S., and C. H. Harrison. 1999. Manufacturing-based relatedness, synergy, and coordination. Strategic Management Journal 20: 129-145.

Starr, J. A., and I. C. MacMillan. 1990. Resource cooptation via social contracting: Resource acquisition strategies for new ventures. Strategic Management Journal 11: 79-92.

Stephan, P. E. 1996. The economics of science. Journal of Economic Literature 34: 1199-1235.

Sternberg, R. 1996. Technology policies and the growth of regions. Small Business Economics 8(2): $75-86$.

Stone, J. 2005. Working to revive South Carolina's apparel industry. Business and Economic Review 51: $3-7$.

Storper, M. 1992. The limits to globalization: Technology districts and international trade. Economic Geography 68: 60-93.

—. 1993. Regional "worlds" of production learning and innovation in technology districts of France, Italy and the USA. Regional Studies 27: 433-456.

- 1995. The resurgence of regional economies: Ten years later. European Urban and Regional Studies 2: 191-221.

Sturgeon, T. J. 2000. How Silicon Valley came to be. In Understanding Silicon Valley: The anatomy of an entrepreneurial region, ed. M. Kenney, pp 15-47. Stanford, CA: Stanford University Press.

Sull, D. N., R. S. Tedlow, and R. S. Rosenbloom. 1997. Managerial commitments and technological change in the U.S. tire industry. Industrial and Corporate Change 6(1997): 461-501.

Teece, D. J., G. Pisano, and A. Shuen. 1997. Dynamic capabilities and strategic management. Strategic Management Journal 18: 509-533.

Tushman, M. L., and P. Anderson. 1986. Technological discontinuities and dominant design: A cyclical model of technological change. Administrative Science Quarterly 35: 604-633.

U.S. Small Business Administration. 2001. Small business economic indicators 2000. Washington, DC: U.S. Small Business Administration Office of Advocacy.

Uzzi, B. 1997. Social structure and competition in interfirm networks: The paradox of embeddedness. Administrative Science Quarterly 42: 35-67.

Van de Ven, A. H., and D. Polley. 1992. Learning while innovating. Organization Science 3: 92-116.

Wernerfelt, B. 1984. A resource-based view of the firm. Strategic Management Journal 5: 171-180.

Williamson, O. E. 1991. Comparative economic organization: The analysis of discrete structural alternatives. Administrative Science Quarterly 36: 269-296.

Zhang, J. 2003. High-tech start-ups and industry dynamics in Silicon Valley. San Francisco: Public Policy Institute of California.

Zucker, L. G., M. R. Darby, and J. S. Armstrong. 1998. Geographically localized knowledge: Spillovers or markets? Economic Inquiry 36: 65-86. 